\title{
Hypertrophic olivary degeneration mimics relapse in neuromyelitis optica spectrum disorder
}

Elia Sechi, MD, Natalie E. Parks, MD, Kelly K. Koeller, MD, and Eoin P. Flanagan, MD

Correspondence

Neurology ${ }^{\circledR}$ 2019;92:343-344. doi:10.1212/WNL.0000000000006930

Dr. Flanagan

flanagan.eoin@mayo.edu

Figure 1 Brain MRI at onset (top row) and after 9 months (bottom row)
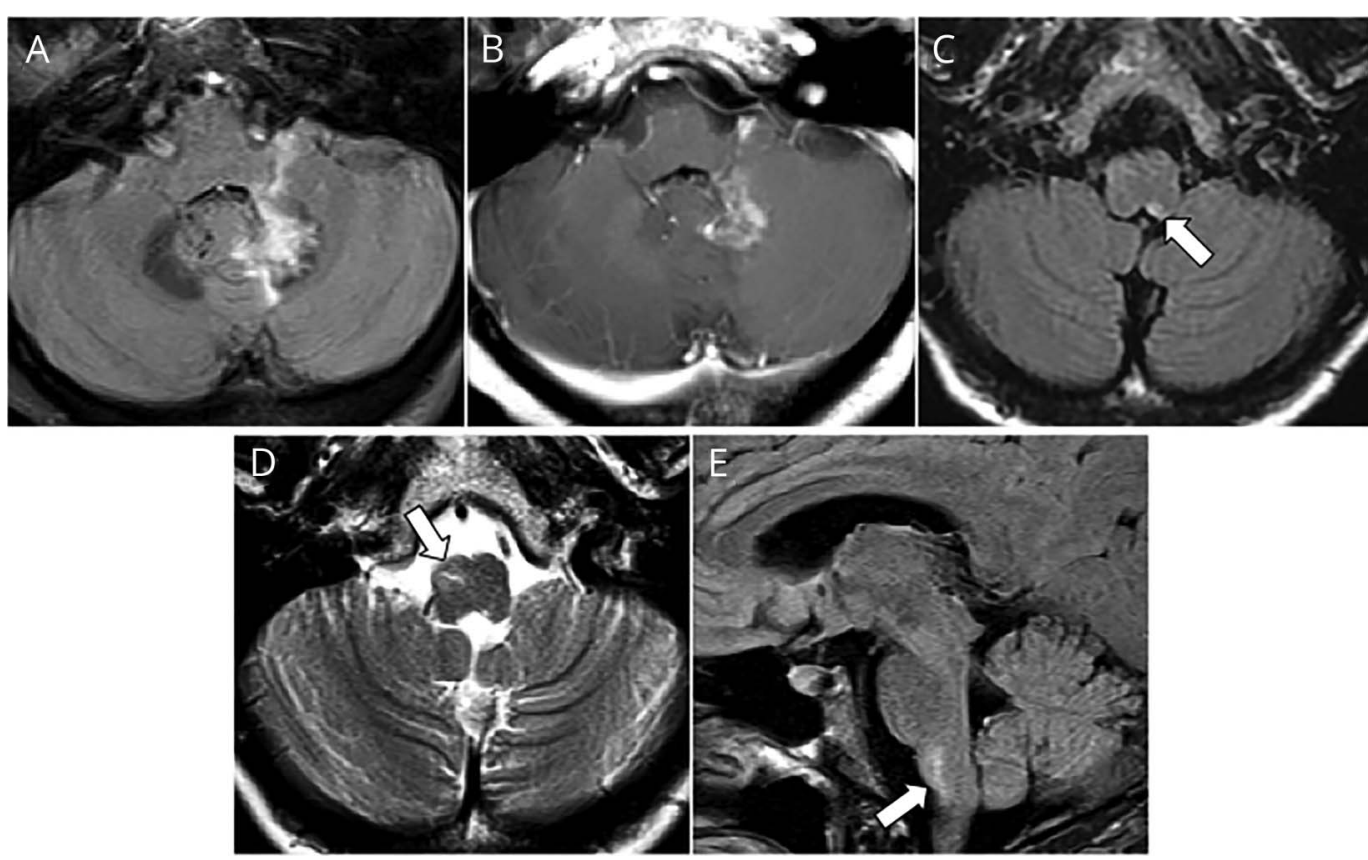

Axial images show T2 hyperintensity of left dentate (A), with enhancement postgadolinium (B), and area postrema T2 hyperintensity (C). Repeat MRI shows right inferior olivary nucleus T2 hyperintensity/hypertrophy on axial (D) and sagittal (E) images.

A 51-year-old woman developed subacute ataxia and intractable vomiting. MRI showed left dentate and area postrema lesions (figure 1, A-C). Serum aquaporin-4-immunoglobulin G positivity confirmed neuromyelitis optica spectrum disorder. Treatment was with steroids and plasmapheresis acutely and maintenance 6-monthly rituximab. MRI 9 months later revealed a new asymptomatic right medullary lesion (figure $1, \mathrm{D}$ and $\mathrm{E}$ ), prompting mycophenolate addon therapy. The hypertrophy, expected location, and time course led us to diagnose hypertrophic olivary degeneration from dentato-rubro-olivary circuit (Mollaret triangle [figure 2]) interruption; no palatal tremor occurred. ${ }^{1,2}$ Mycophenolate was discontinued. Failure to recognize a medullary lesion as hypertrophic olivary degeneration from a prior insult along the Mollaret triangle may lead to unnecessary treatment.

\section{Study funding}

No targeted funding reported.

\section{Disclosure}

The authors report no disclosures relevant to the manuscript. Go to Neurology.org/ $\mathrm{N}$ for full disclosures.

From the Departments of Neurology (E.S., E.P.F.), Radiology (Division of Neuroradiology) (K.K.K.), and Laboratory Medicine and Pathology (E.P.F.), Mayo Clinic, Rochester, MN; and Department of Medicine (Division of Neurology) (N.E.P.), Dalhousie University, Halifax, Canada.

Go to Neurology.org/N for full disclosures. Funding information and disclosures deemed relevant by the authors, if any, are provided at the end of the article. 
Figure 2 Mollaret triangle

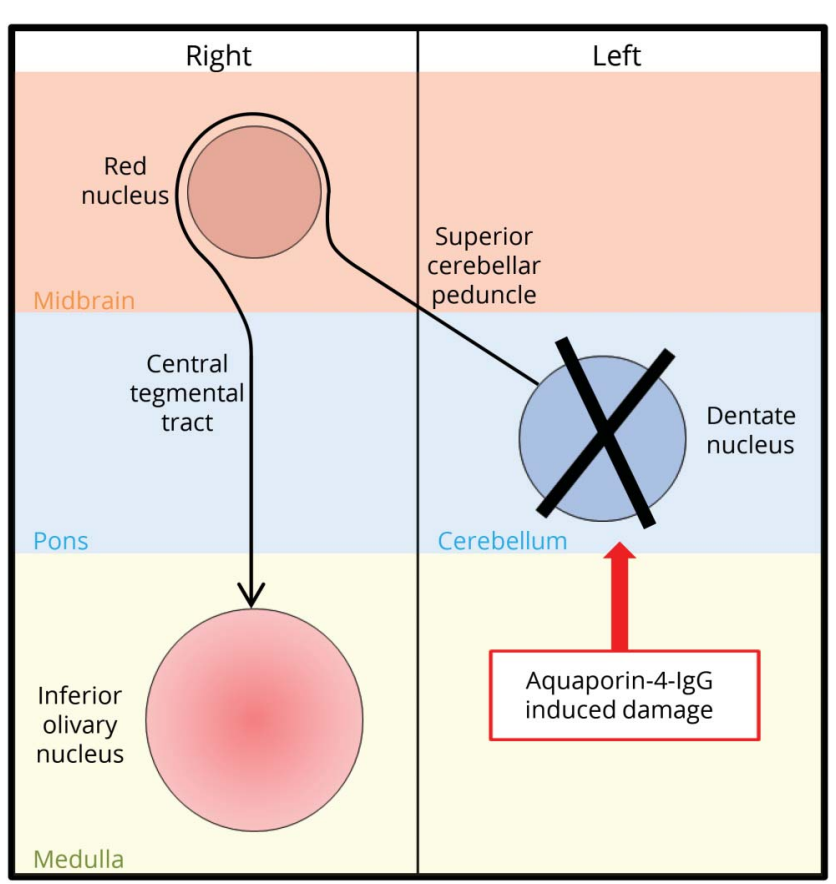

Interruption of dentate fibers to red nucleus after an insult results in contralateral inferior olivary nucleus deafferentation and hypertrophy. IgG = immunoglobulin G.
Appendix Authors

\begin{tabular}{|c|c|c|c|}
\hline Name & Location & Role & Contribution \\
\hline $\begin{array}{l}\text { Elia } \\
\text { Sechi }\end{array}$ & $\begin{array}{l}\text { Mayo Clinic, } \\
\text { Rochester, MN }\end{array}$ & Author & $\begin{array}{l}\text { Drafted manuscript, analyzed } \\
\text { and interpreted the data, } \\
\text { composed the figure }\end{array}$ \\
\hline $\begin{array}{l}\text { Natalie } \\
\text { E. Parks }\end{array}$ & $\begin{array}{l}\text { Dalhousie } \\
\text { University, } \\
\text { Halifax, Canada }\end{array}$ & Author & $\begin{array}{l}\text { Interpreted the data, revised } \\
\text { the manuscript for intellectual } \\
\text { content }\end{array}$ \\
\hline $\begin{array}{l}\text { Kelly K. } \\
\text { Koeller }\end{array}$ & $\begin{array}{l}\text { Mayo Clinic, } \\
\text { Rochester, MN }\end{array}$ & Author & $\begin{array}{l}\text { Interpreted the data, revised } \\
\text { the manuscript for intellectual } \\
\text { content }\end{array}$ \\
\hline $\begin{array}{l}\text { Eoin P. } \\
\text { Flanagan }\end{array}$ & $\begin{array}{l}\text { Mayo Clinic, } \\
\text { Rochester, MN }\end{array}$ & Author & $\begin{array}{l}\text { Designed and conceptualized } \\
\text { study, analyzed and } \\
\text { interpreted the data, } \\
\text { revised the manuscript for } \\
\text { intellectual content, study } \\
\text { supervision }\end{array}$ \\
\hline
\end{tabular}

\section{References}

1. Murdoch S, Shah P, Jampana R. The Guillain-Mollaret triangle in action. Pract Neurol 2016;16:243-246.

2. Goyal M, Versnick E, Tuite P, et al. Hypertrophic olivary degeneration: metaanalysis of the temporal evolution of MR findings. AJNR Am J Neuroradiol 2000;21:1073-1077.

\section{New AAN Practice Management Webinar Format Digs Deeper}

The new format offers a live, 30- to 45-minute webinar with expert faculty followed by several shorter recorded online lectures that explore the topic in greater depth. Each topic concludes with a 30-minute live webchat for further participant Q\&A. Purchase a single webinar series for $\$ 99$ or purchase a 2019 Practice Management Webinar subscription for only \$189-that's less than $\$ 32$ per webinar!

\section{Webinar Series}

- January 15 - Boss, MD: Managing a Better Practice

- March 12 - Understanding How You Get Paid

- May 21 - Everything You Wanted to Know About Your Patients but Were Afraid to Ask: Having Difficult Conversations with Patients from Vulnerable Populations

- August 13 - Increasing Revenue in Your Practice: Care Models, Ancillary Services, and Other Strategies

- October 1 - Using Technology for Better Practice Management of Stroke

- November 19 - Seeing the Future Clearly: How to Succeed in 2020

Learn more and register at AAN.com/view/webinar. 


\section{Neurology}

\section{Hypertrophic olivary degeneration mimics relapse in neuromyelitis optica spectrum disorder}

Elia Sechi, Natalie E. Parks, Kelly K. Koeller, et al.

Neurology 2019;92;343-344

DOI 10.1212/WNL.0000000000006930

This information is current as of February 11, 2019

Updated Information \& Services

References

Permissions \& Licensing

Reprints including high resolution figures, can be found at: http://n.neurology.org/content/92/7/343.full

This article cites 2 articles, 1 of which you can access for free at: http://n.neurology.org/content/92/7/343.full\#ref-list-1

Information about reproducing this article in parts (figures,tables) or in its entirety can be found online at:

http://www.neurology.org/about/about_the_journal\#permissions

Information about ordering reprints can be found online:

http://n.neurology.org/subscribers/advertise

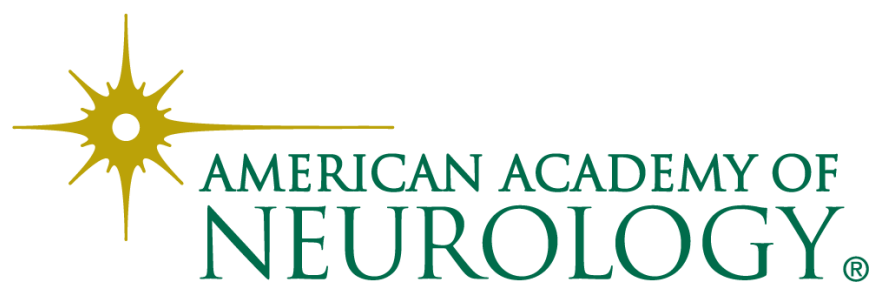

